\title{
Salt-induced changes in antioxidative enzyme activities in root tissues do not account for the differential salt tolerance of two cowpea cultivars
}

\author{
Josemir M. Maia ${ }^{1}$, Eduardo L. Voigt ${ }^{1}$, Cristiane E. C. Macêdoํㅜ, Sérgio L. Ferreira-Silva², \\ Joaquim A. G. Silveira ${ }^{2^{*}}$
}

${ }^{1}$ Laboratório de Estudos em Biotecnologia Vegetal, Departamento de Biologia Celular e Genética, Centro de Biociências, Universidade Federal do Rio Grande do Norte, Campus Universitário Lagoa Nova, CP 1648, CEP 59078-970, Natal, RN, Brasil.

${ }^{2}$ Laboratório de Metabolismo de Plantas, Departamento de Bioquímica e Biologia Molecular, Universidade Federal do Ceará, Campus do Pici, CP 6004, CEP 60455-970, Fortaleza, CE, Brasil.

* Corresponding author: silveira@ufc.br

Received: 05 November 2009; Accepted: 25 August 2010.

\begin{abstract}
The salt stress effect in root growth and antioxidative response were investigated in two cowpea cultivars which differ in salt tolerance in terms of plant growth and leaf oxidative response. Four-day-old seedlings (establishment stage) were exposed to 100 $\mathrm{mM} \mathrm{NaCl}$ for two days. The roots of the two cultivars presented distinct response in terms of salt-induced changes in elongation and dry weight. Root dry weight was only decreased in Pérola (sensitive) cultivar while root elongation was mainly hampered in Pitiúba (tolerant). Root relative water content remained unchanged under salinity, but root $\mathrm{Na}^{+}$content achieved toxic levels as revealed by the $\mathrm{K}^{+} / \mathrm{Na}^{+}$ratio in both cultivars. Then, root growth inhibition might be due to ionic toxicity rather than by salt-induced water deficit. Although electrolyte leakage markedly increased mainly in the Pérola genotype, lipid peroxidation decreased similarly in both saltstressed cultivars. APX and SOD activities were reduced by salinity in both cultivars reaching similar values despite the decrease in Pitiúba had been higher compared to respective controls. CAT decreased significantly in Pitiúba but did not change in Pérola, while POX increased in both cultivars. The salt-induced decrease in the CAT activity of Pitiúba root is, at principle, incompatible to allow a more effective oxidative protection. Our results support the idea that the activities of SOD, APX, CAT and POX and lipid peroxidation in cowpea seedling roots were not associated with differential salt tolerance as previously characterized in terms of growth rate and oxidative response in plant leaves.
\end{abstract}

Key words: antioxidative enzymes, oxidative stress, root growth inhibition, salt stress, Vigna unguiculata

\section{RESUMO}

0 objetivo deste trabalho foi avaliar o efeito do estresse salino sob o crescimento radicular e a atividade de enzimas antioxidantes em duas cultivares de feijão caupi contrastantes em termos de crescimento e resposta oxidativa de folhas. Plântulas com quatro dias de idade foram expostas a $\mathrm{NaCl} 100 \mathrm{mM}$ durante dois dias sob condições controladas. A massa seca das raízes foi afetada somente na cultivar Pérola (sensível) enquanto que o comprimento radicular foi mais reduzido na Pitiúba (resistente). 0 estresse salino não afetou o conteúdo relativo de água, contudo o conteúdo de $\mathrm{Na}^{+}$nas raízes atingiu níveis tóxicos de acordo com a razão 
$\mathrm{K}^{+} / \mathrm{Na}^{+}$em ambas as cultivares, indicando que a inibição do crescimento radicular pode ser estar mais relacionada à toxicidade iônica mais do ao estresse osmótico induzido pelo sal. Embora o vazamento de eletrólitos tenha aumentado principalmente na cultivar sensível, a peroxidação de lipídeos decresceu de forma similar em ambas as cultivares. As atividades de APX e SOD foram diminuídas pela salinidade nas duas cultivares, atingindo valores similares, apesar do decréscimo em Pitiúba ter sido maior, em relação aos controles. A atividade de CAT diminuiu significantemente em Pitiúba, mas permaneceu inalterada em Pérola. 0 decréscimo na atividade de CAT em Pitiúba é, em princípio, incompatível com maior proteção oxidativa. Nossos resultados evidenciam que as atividades de SOD, APX, CAT e POX e a peroxidação de lipídeos em raízes de plântulas de feijão caupi não são compatíveis com tolerância diferencial a salinidade como foi previamente caracterizado por meio do crescimento e resposta oxidativa de folhas de plantas.

Palavras-chave: enzimas antioxidantes, estresse oxidativo, inibição do crescimento radicular, estresse salino, Vigna unguiculata

\section{INTRODUCTION}

Salt stress has become one of the most damaging environmental hazards to crop productivity all over the world (Ashraf and Ali, 2008). This adverse environmental condition impairs plant growth by both water deficit and ionic toxicity (Munns and Tester, 2008). Firstly, the hyperosmolarity of the soil solution restricts water uptake by the roots and triggers transient changes in the plant water relations (Bray et al., 2000; Munns and Tester, 2008). Secondly, the accumulation of saline ions in the tissues leads to the salt-specific toxic effects on the plant metabolism (Maathuis and Amtmann, 1999; Apse and Blumwald, 2007).

As the roots are directly exposed to salt, they may be the most vulnerable organs (Munns and Tester, 2008). Indeed, root growth inhibition has been extensively reported as a primary response in plants submitted to salt stress. Root growth may be affected by salt in terms of fresh weight (Lin and Kao, 2002; Jebara et al., 2005; Khan and Panda, 2008), dry weight (Ashraf and Hamad, 2000; Lin and Kao, 2002; Chaparzadeh et al., 2004, Ferreira-Silva et al., 2008), relative growth rate (Jeschke et al., 1986; Sibole et al., 2003), and root length (Wahid et al., 1998; Kopyra and Gwóźdź, 2003). Salt stress also triggers changes in root morphology, inhibiting the initiation and the elongation of lateral roots (Rubbinigg et al., 2004).

Recent evidences indicate that root growth inhibition under salt stress may be related to changes in the oxidative metabolism. The reactive oxygen species (ROS), including superoxide anion $\left(\mathrm{O}_{2}{ }^{\circ}\right)$, hydrogen peroxide $\left(\mathrm{H}_{2} \mathrm{O}_{2}\right)$ and hydroxyl radical $\left(\mathrm{OH}^{\circ}\right)$, are normal byproducts of the metabolic activities in mitochondria and peroxisomes (Foyer and Noctor, 2000). However, the salt-induced ROS overproduction may trigger the so-called secondary oxidative stress due to oxidative damages on lipids, proteins and nucleic acids (Møller, 2007).
On the other hand, if ROS production is maintained under tight regulation, these molecules may be involved in cell signaling and key reactions of cell elongation (Carol and Dolan, 2006; Gapper and Dolan, 2006).

It appears that the oxidative metabolism in the apoplast play a central part in root cell elongation. The plasma membrane NADPH oxidase is the main source of apoplastic ROS, producing $\mathrm{O}_{2}{ }^{--}$from NADPH and $\mathrm{O}_{2}$. The generated $\mathrm{O}_{2}{ }^{-}$ is dismutated in $\mathrm{H}_{2} \mathrm{O}_{2}$ by the apoplastic superoxide dismutase (apoplastic SOD), supplying $\mathrm{H}_{2} \mathrm{O}_{2}$ as a substrate for the cellwall peroxidases (cell-wall POXs) (Gapper and Dolan, 2006). The cell-wall POXs display multiple functions in the apoplastic oxidative metabolism. These enzymes may detoxify excessive $\mathrm{H}_{2} \mathrm{O}_{2}$ as well as generate $\mathrm{OH}^{\circ}$ from $\mathrm{O}_{2}{ }^{-}$and $\mathrm{H}_{2} \mathrm{O}_{2}$ (Passardi et al., 2004). In the first case, the excessive $\mathrm{H}_{2} \mathrm{O}_{2}$ is used as an oxidant for phenylpropanoid crosslinking during lignin biosynthesis, limiting cell elongation (Passardi et al., 2004). In the second, the generated $\mathrm{OH}^{*}$ cleaves the crosslinkiey polysaccharides enabling wall stretching and cell elongation (Liszkay et al., 2003). The apoplastic $\mathrm{OH}^{*}$ may also act as a signal during tip growth, stimulating the plasma membrane hyperpolarizationactivated $\mathrm{Ca}^{2+}$ channels (Foreman et al., 2003).

The ROS concentration in the tissues directly exposed to salt are strongly influenced by the coordinated action of different antioxidative enzymes (Munns and Tester, 2008). In this way, salt resistance has been extensively associated with the protective role of antioxidative enzymes against saltinduced oxidative stress (Mittova et al., 2003). In fact, saltresistant cultivars of millet (Sreenivasulu et al., 2000), rice (Vaidyanathan et al., 2003), cotton (Meloni et al., 2003), maize (Azevedo-Neto et al., 2006) and cashew (Abreu et al., 2008) show enhanced activity of different antioxidative enzymes. In a previous work, it appears that the ability of cowpea [Vigna 
unguiculata (L.) Walp.] plants to survive under salinity is not related to an operating antioxidant system involving SOD, CAT and POX activity in mature leaves (Cavalcanti et al., 2004).

Although roots may firstly suffer salt-induced injuries as they are directly exposed to salinity (Munns, 2002), little work has been done on roots with regard to antioxidant responses under salt stress (Cavalcanti et al., 2007). Recently, we have demonstrated that the differential salt tolerance between two cowpea cultivar, at the stage of rapid growth, was associated with favorable response of SOD, APX, CAT and POX in leaves (Maia et al., 2010). In present work we test the hypothesis that roots of two contrasting cowpea cultivars at seedling establishment stage display contrasting response in terms of growth, $\mathrm{Na}^{+}$accumulation, lipid peroxidation and SOD, APX, CAT and POX activities in response to a high $\mathrm{NaCl}$ level under short-term exposure.

\section{MATERIAL AND METHODS}

Plant material and experimental conditions: Cowpea seeds [Vigna unguiculata (L.) Walp.], Pérola and Pitiúba cultivars were obtained from the Departmento de Fitotecnia of the Universidade Federal do Ceará. These two cultivar were previously characterized as salt-sensitive (Pérola) and salt-tolerant (Pitíuba) in the stages of germination and mature plants (Freitas, 2006). Recently, the growth contrast between these two cultivars was associated with the oxidative response in leaves of plants at the rapid growth stage (Maia et al., 2010). Seeds were surface-disinfected in $70 \%$ (v/v) ethanol for $1 \mathrm{~min}$, followed by $5 \%(\mathrm{w} / \mathrm{v}$ ) sodium hypochlorite for $5 \mathrm{~min}$ and then rinsed two times with sterile deionized water. After that, the seeds were imbibed during 20 min and sowed in germination paper $(28 \times 38 \mathrm{~cm})$ moistened with sterile deionized water (2.5 $\mathrm{mL}$ of water per $1 \mathrm{~g}$ of paper) according to Vieira and Carvalho (1994). The seeds were incubated under controlled conditions $\left(240 \mu \mathrm{mol} \mathrm{m}^{-2} \mathrm{~s}^{-1}, 12 \mathrm{~h}\right.$ photoperiod, $27 \pm 2^{\circ} \mathrm{C}$ and $70 \pm 10 \%$ of relative humidity) during 4 days.

Four-day-old seedlings were transferred to paper moistened with sterile deionized water (control) or $100 \mathrm{mM} \mathrm{NaCl}$ (salt treatment) and maintained at the same conditions for 2 days. Then, the seedlings were harvested and samples of fresh roots were utilized to the measurement of root length $(\mathrm{RL})$, fresh weight (FW), relative water content (RWC), and electrolyte leakage (EL). Also, fresh samples were immediately frozen in liquid $\mathrm{N}_{2}$ and stored to $-80^{\circ} \mathrm{C}$ for further biochemical determinations. Samples dried at $70^{\circ} \mathrm{C}$ during 2 days were used in the determination of root dry weight (DW) and $\mathrm{Na}^{+}$and $\mathrm{K}^{+}$content.

Root length, dry weight, relative water content, electrolyte leakage and $\mathrm{Na}^{+}$and $\mathrm{K}^{+}$content: The root length was measured using a paquimetro. The relative water content (RWC) was measured according to Cairo (1995). In brief, five root segments $(5.0 \mathrm{~cm}$ in length) from the root-shoot junction were sampled, immediately weighed (FW) and then immersed in distilled water at $25^{\circ} \mathrm{C}$ for $6 \mathrm{~h}$. After that, the segments were blotted onto filter paper and the turgid weight (TW) was determined. Then, the segments were dried at $70^{\circ} \mathrm{C}$ for 2 days and the dry weight (DW) was obtained. The RWC was calculated using the equation $\mathrm{RWC}=(\mathrm{FW}-\mathrm{DW}) /(\mathrm{TW}-\mathrm{DW}) \times 100$.

Membrane damage was estimated by electrolyte leakage (EL) as previously described by Blum and Ebercon (1981). Fifteen segments $(5.0 \mathrm{~cm}$ in length) from the root tip were transferred to test tubes containing $10 \mathrm{~mL}$ of deionized water. The segments were incubated at $25^{\circ} \mathrm{C}$ for $6 \mathrm{~h}$ and the electric conductivity of the leachate was measured $\left(L_{1}\right)$. After that, the segments were boiled for $60 \mathrm{~min}$, cooled to $25^{\circ} \mathrm{C}$ and the electric conductivity was measured again $\left(L_{2}\right)$. The percentage of electrolyte leakage was estimated by the relation $\mathrm{EL}(\%)=\left(L_{1} / L_{2}\right) \times 100$.

The $\mathrm{Na}^{+}$and $\mathrm{K}^{+}$content of the root tissues were determined by flame photometry. Dry roots were finely powdered and samples of $50 \mathrm{mg}$ were extracted with $10 \mathrm{~mL}$ of deionized water at $100^{\circ} \mathrm{C}$ for 60 min in hermetically closed tubes. After cooling, the extract was filtered through cotton cloth and the $\mathrm{Na}^{+}$and $\mathrm{K}^{+}$content was determined.

Lipid peroxidation: Lipid peroxidation was determined by measuring malonaldehyde (MDA) formation by the thiobarbituric acid method in accordance with Heath and Packer (1968). For MDA extraction, samples of $50 \mathrm{mg}$ of fresh roots were homogenized with $2 \mathrm{~mL}$ of $1 \%$ (w/v) trichloroacetic acid (TCA). The homogenate was centrifuged at $10,000 \mathrm{~g}$ for $10 \mathrm{~min}$. Aliquots of $1 \mathrm{~mL}$ of the MDA extract were added to $2 \mathrm{~mL}$ of $20 \%(\mathrm{w} / \mathrm{v})$ TCA containing $0.5 \%(\mathrm{w} / \mathrm{v})$ thiobarbituric acid (TBA). The mixture was heated at $95^{\circ} \mathrm{C}$ for $30 \mathrm{~min}$ and then cooled quickly on an ice bath. Thus, the mixture was centrifuged at 10,000 $\mathrm{g}$ for $15 \mathrm{~min}$ and the absorbance of the supernatant was measured at $532 \mathrm{~nm}$. Measurements were corrected for unspecific turbidity by subtracting the absorbance at $660 \mathrm{~nm}$. The MDA concentration was calculated using the extinction coefficient of $155 \mathrm{mM}^{-1} \mathrm{~cm}^{-1}$. 
Enzyme assays: Soluble proteins were extracted as described previously by Cakmak and Horst (1991) with some modifications. Samples of $1.0 \mathrm{~g}$ of fresh roots were finely powdered with liquid $\mathrm{N}_{2}$ and homogenized during 3 min in 3 $\mathrm{mL}$ ice-cold $50 \mathrm{mM}$ phosphate buffer, pH 7.0, containing 0.1 $\mathrm{mM}$ EDTA and $1 \mathrm{mM} \mathrm{L-ascorbic} \mathrm{acid.} \mathrm{After} \mathrm{filtration} \mathrm{through}$ cheesecloth, the homogenate was centrifuged at $13,000 \mathrm{~g}$ for 15 min and the supernatant was used as the enzyme crude extract. All the steps were carried out at $0-4^{\circ} \mathrm{C}$. The protein content of the extracts was estimated according to Bradford (1976), using bovine serum albumin as standard.

The superoxide dismutase (SOD - EC 1.15.1.1) activity was determined through inhibition of blue formazane production by NBT photoreduction. The reaction medium contained 100 $\mu \mathrm{L}$ of the enzyme extract, $13 \mathrm{mM}$ L-methionine, $75 \mu \mathrm{M} \mathrm{p}$-nitro blue tetrazolium chloride (NBT), $100 \mu \mathrm{M}$ EDTA and $20 \mu \mathrm{M}$ riboflavin dissolved in $50 \mathrm{mM}$ potassium phosphate buffer, $\mathrm{pH} 7.8$, in a final volume of $2 \mathrm{~mL}$. The reaction took place in a chamber under illumination of a $30 \mathrm{~W}$ fluorescent lamp at $25^{\circ} \mathrm{C}$. The reaction was started turning the fluorescent lamp on and stopped 5 min later turning it off (van Rossun et al., 1997). The blue formazane produced by NBT photoreduction was measured by the increase in the absorbance at $560 \mathrm{~nm}$. The control reaction mixture had no enzyme extract. The blank solution had the same complete reaction mixture but it was kept in the dark. One SOD AU was defined as the amount of enzyme required to inhibit 50\% of the NBT photoreduction in comparison with tubes lacking the enzyme extract. The

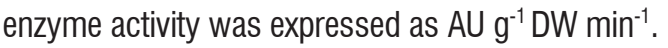

The activity of ascorbate peroxidase (APX-EC.1.11.1.11) was measured following the ascorbate (AsA) oxidation by the decrease in absorbance at $290 \mathrm{~nm}$ according to Nakano and Asada (1981). The reaction mixture of $3 \mathrm{~mL}$ contained 100 $\mu \mathrm{L}$ of the enzyme preparation, $0.5 \mathrm{mM}$ AsA and $0.1 \mathrm{mM}$ EDTA dissolved in $100 \mathrm{mM}$ potassium phosphate buffer, pH 7.0. The reaction was started by adding $200 \mu \mathrm{L}$ of $30 \mathrm{mM} \mathrm{H}_{2} \mathrm{O}_{2}$. The enzyme activity was measured at $290 \mathrm{~nm}$ and $30^{\circ} \mathrm{C}$ after $60 \mathrm{~s}$, calculated according to the molar extinction coefficient of $2.8 \mathrm{mM}^{-1} \mathrm{~cm}^{-1}$ and expressed as $\mu \mathrm{mol} \mathrm{AsA} \mathrm{g}{ }^{-1} \mathrm{DW} \mathrm{min}{ }^{-1}$.

The catalase (CAT - EC 1.11.1.6) activity was determined following the oxidation of $\mathrm{H}_{2} \mathrm{O}_{2}$ at $240 \mathrm{~nm}$. The reaction was started by adding $50 \mu \mathrm{L}$ of enzyme extract in a reaction medium of $2.95 \mathrm{~mL}$ containing $50 \mathrm{mM}$ potassium phosphate buffer, $\mathrm{pH}$ 7.0 , and $20 \mathrm{mM} \mathrm{H}_{2} \mathrm{O}_{2}$. The enzyme activity was determined by measuring the decrease in absorbance at $240 \mathrm{~nm}$ and $30^{\circ} \mathrm{C}$ after 60s (Havir and Mchale, 1987), was calculated using the molar extinction coefficient of $36 \times 10^{3} \mathrm{mM}^{-1} \mathrm{~cm}^{-1}$ for $\mathrm{H}_{2} \mathrm{O}_{2}$ and expressed in $\mu$ mol oxidized $\mathrm{H}_{2} \mathrm{O}_{2} \mathrm{~g}^{-1} \mathrm{DW} \mathrm{min}^{-1}$.

The activity of phenol peroxidase (POX - EC 1.11.1.7) was determined on the basis of purpurogallin formation from pyrogallol. The reaction mixture of $5 \mathrm{~mL}$ contained $50 \mathrm{mM}$ potassium phosphate buffer, pH 6.8, $20 \mathrm{mM}$ guaiacol, $20 \mathrm{mM}$ $\mathrm{H}_{2} \mathrm{O}_{2}$ and $25 \mu \mathrm{L}$ of enzyme preparation. After incubation at $30^{\circ} \mathrm{C}$ for $10 \mathrm{~min}$, the reaction was stopped by adding $0.5 \mathrm{~mL}$ of $5 \%(\mathrm{v} / \mathrm{v}) \mathrm{H}_{2} \mathrm{SO}_{4}$ and the absorbance was read at $480 \mathrm{~nm}$ (Urbanek et al., 1991). The guaiacol peroxidase activity was expressed as $\mu \mathrm{mol}$ purpurogallin $\mathrm{g}^{-1} \mathrm{DW} \mathrm{min}^{-1}$.

Experimental design and statistical analysis: The experiments were carried out in a completely randomized design with two treatments and two cultivars. Three replicates were performed per treatment and each replicate contained the roots of 13 seedlings. The results were submitted to variance analyses (ANOVA) and means were compared by the Tukey's test at $5 \%$ of significance.

\section{RESULTS}

In this work, the roots of two cowpea cultivar, at seedling establishment stage, previously characterized as salt-sensitive (Pérola) and salt-tolerant (Pitiúba), in the stages of germination and mature plants, by a screening of 55 cowpea genotypes (Freitas, 2006). Recently, these two contrasting cultivars displayed distinct oxidative response in leaves under salinity at the plant rapid growth stage (Maia et al., 2010). In this current work cowpea cultivars showed different responses to salt stress in terms of growth and antioxidative enzyme activity. Although the salt treatment impaired the root growth in both cultivars, differences were verified in the root length $(R L)$ and dry weight (DW), as well as in the root architecture. In the salttreated seedlings, the RL decreased $17 \%$ in Pérola and $33 \%$ in Pitiúba in comparison with the respective untreated seedlings (Figure 1A). The root DW was not significantly changed by the salt treatment in Pitiúba, but it was reduced by $23 \%$ in Pérola with regard to the respective control (Figure 1B). The relative water content (RWC) was not significantly changed by salinity in the roots of both cultivars and remained approximately $83 \%$ in all treatments (Figure 1C).

The $\mathrm{K}^{+}$accumulation decreased by $10 \%$ in both cultivars in comparison to the respective controls (Figure 2A). As expected, $\mathrm{Na}^{+}$accumulation was notably increased after two days at 100 
$\mathrm{mM} \mathrm{NaCl}$, since the root $\mathrm{Na}^{+}$content increased 4.3-fold in the Pérola and 4.5-fold in Pitiúba in relation to the untreated seedlings (Figure 2B). As a consequence of the $\mathrm{Na}^{+}$content increase, the $\mathrm{K}^{+} / \mathrm{Na}^{+}$ratio was dropped by $80 \%$ in the salt-treated seedlings of both cultivars with regard to the respective controls (Figure

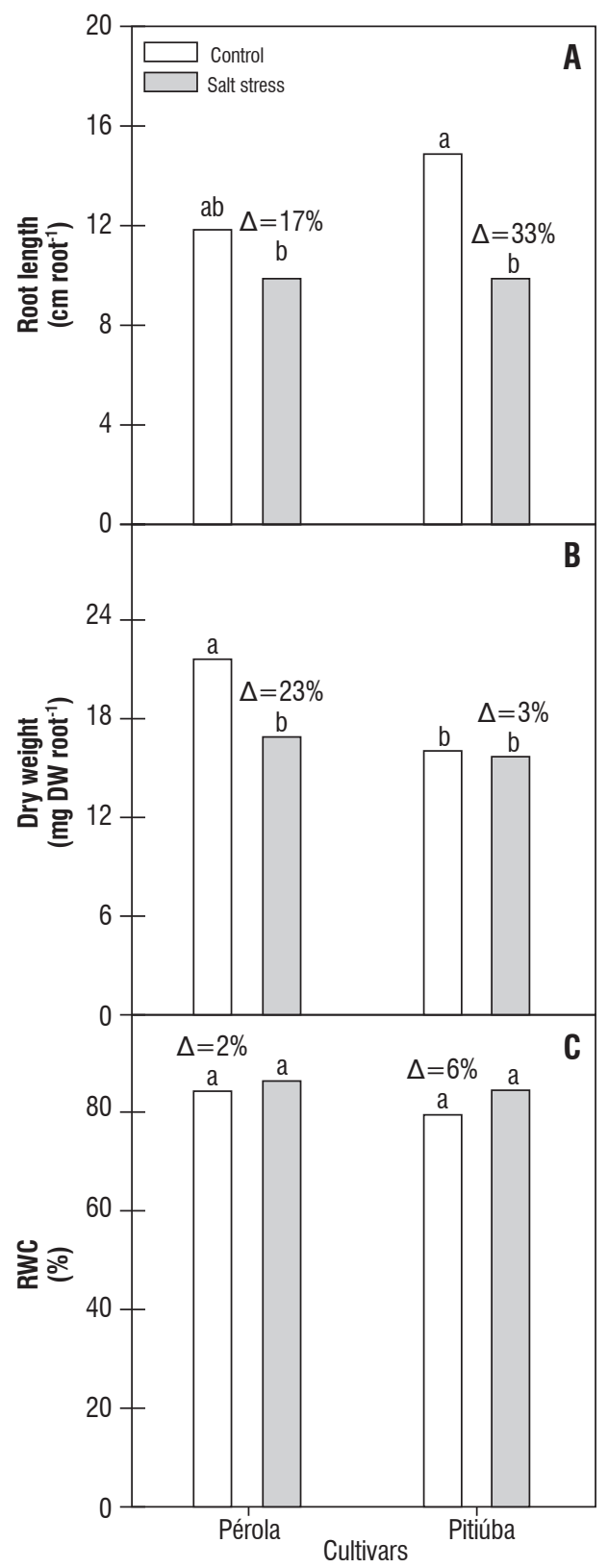

Figure 1. Effect of salt stress on root length (A), dry weight (B) and relative water content $(C)$ of the Pérola (left) and Pitiúba (right) cowpea seedlings. Four-day-old seedlings were grown at controlled conditions and exposed to $100 \mathrm{mM} \mathrm{NaCl}$ during two days. In (A) and (B), gray bars correspond to the salt treatment and white bars represent the untreated control. Values are means of three replicates. Bars signaled with the same lowercase letters do not differ significantly according to the Tukey test $(p=0.05)$.
2C). In the roots of Pitiúba, the electrolyte leakage (EL) increased about 2.4-fold by the salt treatment, whereas in the roots of Pérola it increased by only 2.8-fold (Figure 3A). Conversely, lipid peroxidation decreased about $29 \%$ in the roots of both cultivars under salt stress (Figure 3B).

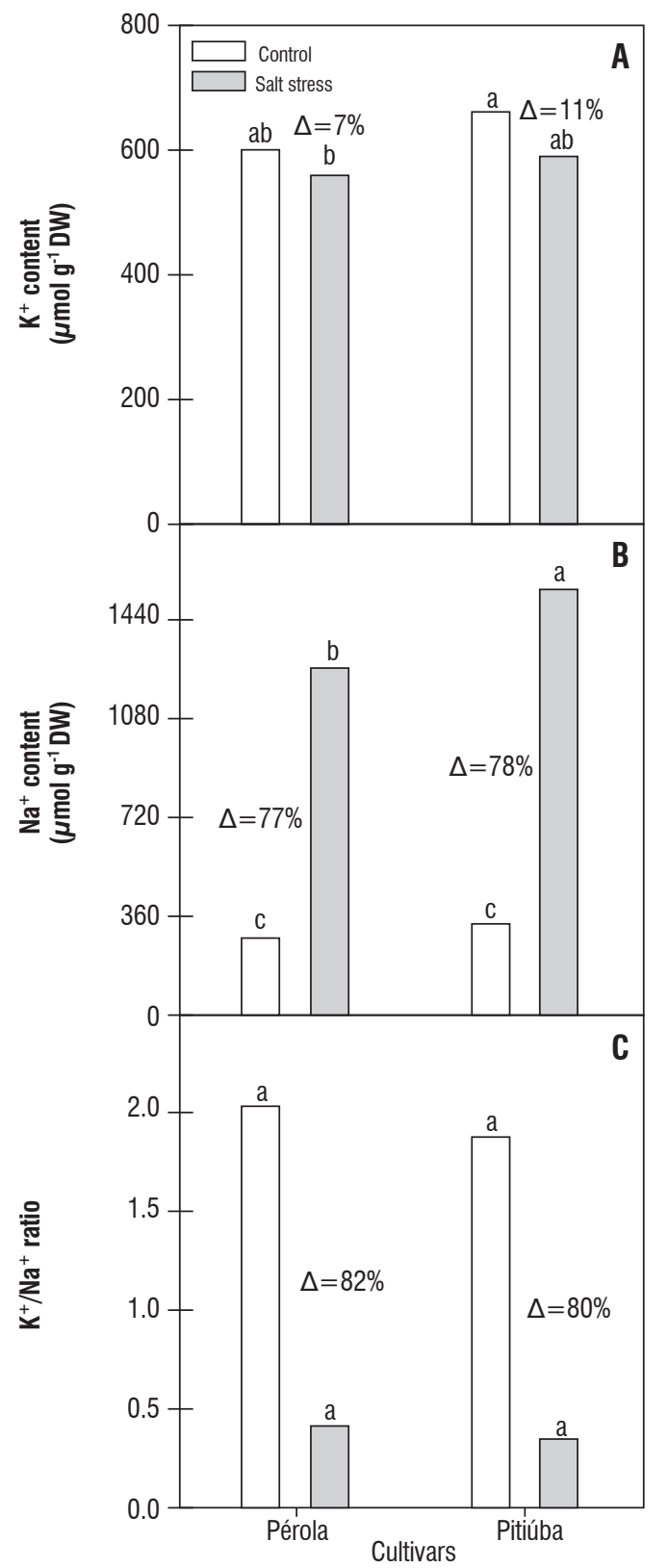

Figure 2. Effect of salt stress on $\mathrm{K}^{+}$content (A), $\mathrm{Na}^{+}$content (B) and $\mathrm{K}^{+}$ $\mathrm{Na}^{+}$ratio $(C)$ in the roots of Pérola (left) and Pitiúba (right) cowpea seedlings. Gray bars correspond to the salt treatment and white bars represent the untreated control. Values are means of three replicates. Bars signaled with the same lowercase letters do not differ significantly according to the Tukey test $(p=0.05)$. 


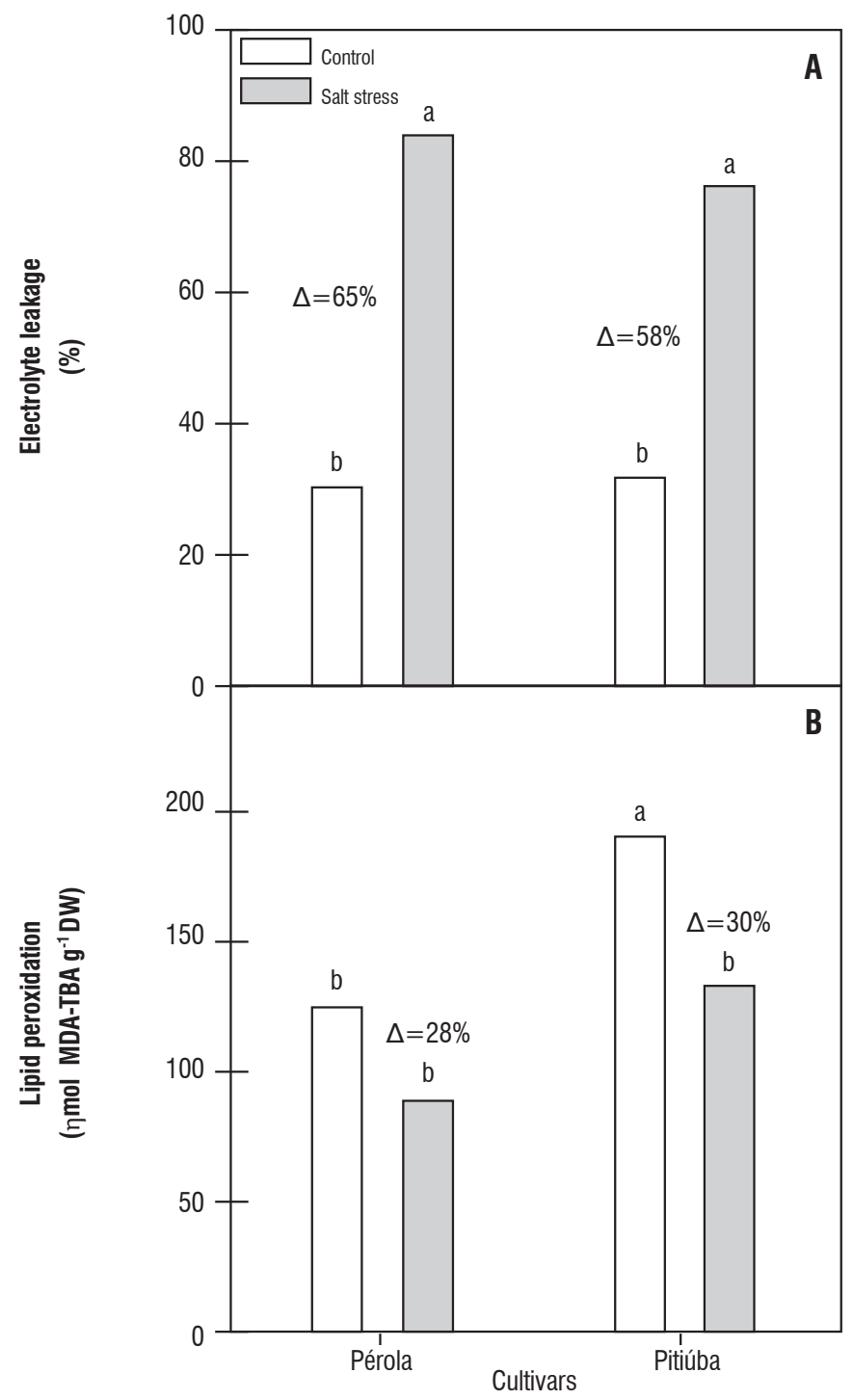

Figure 3. Effect of salt stress on electrolyte leakage (A) and lipid peroxidation (B) in the roots of Pérola (left) and Pitiúba (right) cowpea seedlings. Gray bars correspond to the salt treatment and white bars represent the untreated control. Values are means of three replicates. Bars signaled with the same lowercase letters do not differ significantly according to the Tukey test $(p=0.05)$.

The SOD activity did not show significant changes after two days at $100 \mathrm{mM} \mathrm{NaCl}$ in the roots of Pérola, but it decreased $26 \%$ in the roots of Pitiúba in comparison with the respective control (Figure 4A). In the salt-treated seedlings of both cultivars, the APX activity was reduced by $51 \%$, relative to the untreated seedlings (Figure 4B). The CAT activity decreased by $38 \%$ in the Pitiúba roots and was not altered by the salt treatment in the Pérola roots (Figure 4C). Under $100 \mathrm{mM} \mathrm{NaCl}$, the POX activity increased only about $12 \%$ in the Pérola roots whereas it augmented by $26 \%$ in the Pitiúba roots (Figure 4D). 


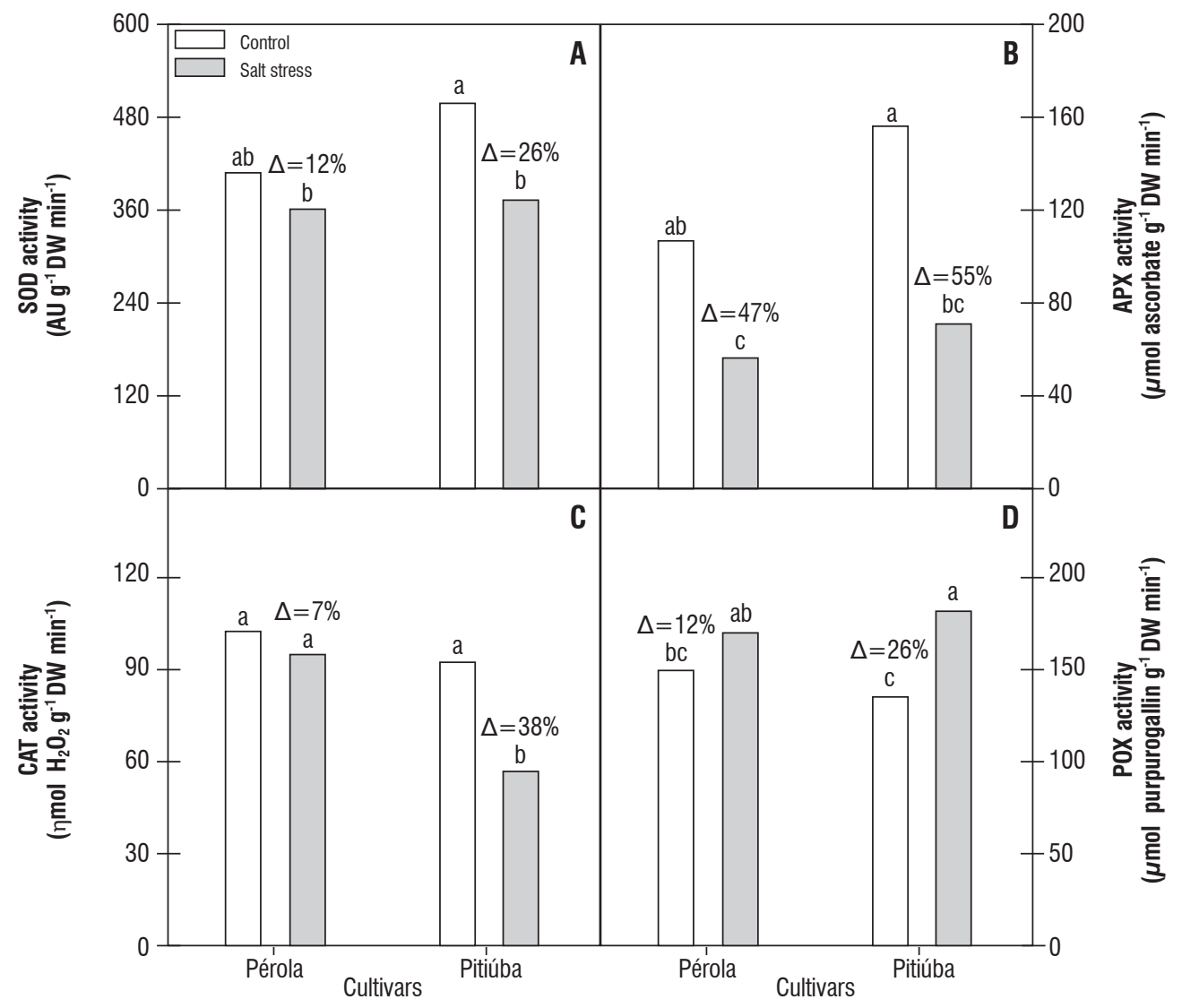

Figure 4. Effect of salt stress on the activity of SOD (A), APX (B), CAT (C) and POX (D) in the roots of Pérola (left) and Pitiúba (right) cowpea seedlings. Gray bars correspond to the salt treatment and white bars represent the untreated control. Values are means of three replicates. Bars signaled with the same lowercase letters do not differ significantly according to the Tukey test $(p=0.05)$.

\section{DISCUSSION}

In this study the root data of lipid peroxidation, membrane integrity and antioxidative enzyme activities were not able to characterize the cowpea Pitiúba and Pérola cultivars as tolerant and sensitive, respectively, to salinity. These cultivars were previously characterized as contrasting in the germination and plant rapid growth stages (Freitas, 2006). Recently, that characterization of these cultivars was corroborated in terms of antioxidative enzyme responses in leaves associated with and plant growth. It is widely accepted that plant response to salinity depend on several factors such as plant organ, stress intensity, physiological stage, environmental factors etc ((Munns and Tester, 2008). In addition, the effective role of the each antioxidative enzyme activities (measured in vitro) in salt tolerance is still contradictory (Cavalcanti et al., 2004).
Root growth inhibition is a primary response in plants submitted to salt stress (Munns and Tester, 2008). Fresh and dry weight, relative growth rate and root length (Khan and Panda, 2008, Ferreira-Silva et al., 2008; Sibole et al., 2003; Kopyra and Gwóźdź, 2003) have been extensively used as good physiological indicators to demonstrate the influence of salt on root growth. In this work, root growth of the Pérola and Pitiúba cowpea cultivars were differentially affected by the exposure to $100 \mathrm{mM} \mathrm{NaCl}$ during 2 days. Although both cultivars showed salt-induced growth inhibition, root dry weight was reduced only in the Pérola. As the primary root showed abnormal morphology, involving enlargement and tip curling, it is possible that both cell division and elongation were hampered by salt (Croser et al., 2001). 
Physiological indicators associated with the plant water status have been utilized to evaluate the osmotic effects of salt stress (Dionisio-Sese and Tobita, 1998), as well as enhanced $\mathrm{Na}^{+}$accumulation and changes in the $\mathrm{K}^{+} / \mathrm{Na}^{+}$ ratio in plant tissues may indicate disturbances in the plant ionic homeostasis (Maathius and Amtmann, 1999; Apse and Blumwald, 2007). In the Pérola and Pitiúba seedlings, the salt treatment did not significantly alter the root RWC, but did promote strong $\mathrm{Na}^{+}$accumulation as estimated on the basis of tissue water in the root (about 110 and $150 \mathrm{mM}$, respectively). This higher $\mathrm{Na}^{+}$concentration in Pitiúba compared to Pérola is unexpected and not easy to explain because the former cultivar exhibits salt tolerance characteristics (Maia et al., 2010).

$\mathrm{K}^{+} / \mathrm{Na}^{+}$ratios (an indicator of $\mathrm{Na}^{+}$toxicity and disruption of $\mathrm{Na}^{+}-\mathrm{K}^{+}$homeostasis) were dramatically dropped in both cultivars, yielding values lower than 0.50 . Taking into account that salt stress affected slightly $\mathrm{K}^{+}$accumulation, it can be inferred that the salt-induced changes in $\mathrm{K}^{+} / \mathrm{Na}^{+}$ ratios mainly resulted from $\mathrm{Na}^{+}$accumulation. According to the results on the root RCW, $\mathrm{Na}^{+}$content and $\mathrm{K}^{+} / \mathrm{Na}^{+}$ratio, it is likely that root growth inhibition was poorly influenced by salt-induced water deficit and it was mainly due to ionic toxicity. It is suggested that $\mathrm{Na}^{+}$concentrations above 100 $\mathrm{mM}$ may trigger toxic effects on the $\mathrm{K}^{+}$-dependent enzymes (Maathius and Amtmann, 1999; Apse and Blumwald, 2007).

Plant cell membranes are commonly damaged under salt stress. It is proposed that the exposure to salt may directly alter membrane stability, as $\mathrm{Na}^{+}$displaces surface $\mathrm{Ca}^{2+}$ breaking ionic bridges between the head groups of membrane lipids (Cramer et al., 1985; Mengle and Kirkby, 2001). In this study the salinity caused severe damage on the membrane integrity of both cultivars. This effect was more pronounced in the Pérola than was in Pitiúba. In the experimental conditions $\mathrm{NaCl}$ was close to cowpea young roots and possibly the membrane $\mathrm{Na}^{+}$-exclusion mechanism was inefficient in both cultivars (Apse and Blumwald, 2007).

Salt-induced oxidative stress may disrupt membrane structure, because ROS overproduction triggers lipid and protein peroxidation (Dionisio-Sese and Tobita, 1998; Shanker et al., 2004; Mandhania et al., 2006). In this work, electrolyte leakage is markedly increased by salt in the roots of both cultivars, suggesting high membrane damage.
Conversely, lipid peroxidation was significantly decreased in the roots of salt-treated Pérola and Pitiúba seedlings. This is an unexpected response, as high electrolyte leakage is generally accompanied by enhanced lipid peroxidation as an evidence of oxidative damage (Aroca et al., 2003; Shanker et al., 2004; Mandhania et al., 2006). However, decreased lipid peroxidation has been already observed in maize roots (Azevedo-Neto et al., 2006), cowpea roots (Cavalcanti et al., 2007) and cashew roots (Abreu et al., 2009). It is possible that changes in the fatty acid profile of membrane lipids masked the estimation of membrane damage through the TBARS assay (Hamed et al., 2005; Amor et al., 2006). In addition, oxidative injuries on the membrane proteins may also contribute to high electrolyte leakage (Dionisio-Sese and Tobita, 1998; Yang et al., 2004).

Salt resistance has been extensively associated with the protective role of antioxidative enzymes against salt-induced oxidative stress in several salt-resistant cultivars (Mittova et al., 2003; Sreenivasulu et al., 2000; Vaidyanathan et al., 2003; Meloni et al., 2003; Azevedo-Neto et al., 2006). In this work, the so-called salt-sensitive Pérola and salt-resistant Pitiúba, both characterized at germination and vegetative growth stages (Freitas, 2006) displayed similar responses to salt stress in terms of SOD, APX and POX antioxidative enzyme activities. Unexpectedly, the activity of SOD, APX and CAT were more intensively decreased by salt treatment in the Pitiúba than in the Pérola. In addition, CAT activity was strongly decreased in Pitiúba and did not changed by salt effect in Pérola.

The antioxidative enzymatic data found here are unexpected, especially the CAT activity. In roots, this enzyme is located especially into glyoxysomes (Foyer and Noctor, 2000). The significant drop verified in the CAT activity of Pitiúba cultivar roots might indicate a salt-sensitivity or, alternatively, that this cultivar could have a high constitutive level this enzyme in young root tissue able to scavenging $\mathrm{H}_{2} \mathrm{O}_{2}$ excess together other root peroxidases. Working with cowpea plants exposed to high salinity the CAT activity in mature roots of Pitiúba cultivar did not change during six days of salt exposure (Cavalcanti et al., 2007). The characterization of salt resistance just on the basis of enhanced antioxidative enzyme activities may be a simplistic approach taking into account the complexity of the oxidative metabolism, which is typically redundant in higher plants 
(Mitller, 2002). Moreover, it is noteworthy that several species display different oxidative responses under salinity (Sreenivasulu et al., 2000; Meloni et al., 2003; Vaidyanathan et al., 2003).

Among the antioxidative enzyme activities assessed in the root tissues of the cowpea cultivars, only the POX activity was increased in response to the salt treatment. Interestingly, the salt-induced increase in the POX activity was accompanied with a drop in the CAT and APX activities, especially in the Pitiúba roots (Fig. 4). It possibly means that the POX is the main $\mathrm{H}_{2} \mathrm{O}_{2}$-detoxifying enzyme in salt-treated cowpea roots, in accordance with the results obtained for common bean (Jebara et al., 2005), marigold (Chaparzadeh et al., 2004) and rice (Khan and Panda, 2008) roots exposed to salt. Also, salttreated roots of miragold (Chaparzadeh et al., 2004) and rice (Khan and Panda, 2008) show the same trend with regard to the POX and CAT activities.

It has been suggested that the coordinated activity of the different $\mathrm{H}_{2} \mathrm{O}_{2}$-scavenging enzymes play a part in the plant redox homeostasis (Foyer and Noctor, 2005). In this way, the increased POX activity may compensate the reduced CAT and APX activities in the root tissues of cowpea seedlings, avoiding salt-induced oxidative stress, as indicated by decreased lipid peroxidation. However, it remains to be elucidated the mechanisms underlying the coordinated regulation of the antioxidative enzyme activities under salt stress. We have previously reported that in both root and leaf of Pitiúba cultivar the POX activity is strongly salt-up-regulate by salinity (Cavalcanti et al., 2004; Cavalcanti et al., 2007; Maia et al., 2010).

In conclusion, salt-induced root growth inhibition in Pérola and Pitiúba cowpea seedlings is mainly hampered by ionic toxicity than by water deficit. Our results evidence that the activities of SOD, APX, CAT and POX and lipid peroxidation in cowpea seedling roots were not associated with differential salt tolerance as previously characterized in terms of growth rate and oxidative response in plant leaves.

Acknowledgments: To Fundação Cearense de Apoio à Pesquisa (FUNCAP) and Conselho Nacional de Desenvolvimento Científico e Tecnológico (CNPq) for financial support. J. A. G. Silveira is a CNPq fellowship honored researcher. J. M. M. and E.L.V. are professors of Universidade Federal do Rio Grande do Norte.

\section{REFERENCES}

Abreu CEB, Prisco JT, Nogueira ARC, Bezerra MA, Lacerda CFL, Gomes-Filho, $E$ (2008) Physiological and biochemical changes occurring in dwarf-cashew seedlings subjected to salt stress. Braz. J. Plant Physiol. 20:105-118.

Amor NB, Jiménez A, Megdiche W, Lundqvist M, Sevilla F, Abdelly C (2006) Responses of antioxidant systems to $\mathrm{NaCl}$ stress in the halophyte Cakile maritime. Physiol. Plant. 126:446-457.

Apse MP, Blumwald E (2007) $\mathrm{Na}^{+}$transport in plants. FEBS Lett. 581:22472254.

Aroca R, Irigoyen JJ, Sanchez-Diaz M (2003) Drought enhances maize chilling tolerance. II. Photosynthetic traits and protective mechanisms against oxidative stress. Physiol. Plant. 117:540-549.

Ashraf M, Ahmad, S (2000) Influence of sodium chloride on ion accumulation, yield components and fibre characteristics in salt-tolerant and salt-sensitive lines of cotton (Gossypium hirsutum L.) Field Crops Res. 66:115-127.

Ashraf M, Ali Q (2008) Relative membrane permeability and activities of some antioxidant enzymes as the key determinants of salt tolerance in canola (Brassica napus L.). Environ. Exp. Bot. 63:266-273

Azevedo-Neto DD, Prisco JT, Eneas J, de Abreu CEB, Gomes E (2006) Effect of salt stress on antioxidative enzymes and lipid peroxidation in leaves and roots of salt-tolerant and salt-sensitive maize genotypes. Environ. Exp. Bot. 56:87-94.

Blum A, Ebercon A (1981) Cell-membrane stability as a measure of drought and heat tolerance in wheat. Crop Sci. 21:43-47.

Bradford MM (1976) Rapid and sensitive method for quantitation of microgram quantities of protein utilizing principle of protein-dye binding. Anal. Biochem. 72:248-254.

Bray EA, Bailey-Serres J, Weretilnyk E (2000) Responses to abiotic stresses. In: Gruissem W, Buchannan B, Jones R (eds), Biochemistry and molecular biology of plants, pp.1158-1249. American Society of Plant Physiology. Rockville, MD.

Cairo PAR (1995) Relações hídricas de plantas. UESB, Vitória da Conquista.

Cakmak I, Horst WJ (1991) Effect of Aluminum on Lipid-Peroxidation, Superoxide-Dismutase, Catalase, and Peroxidase-Activities in Root-Tips of Soybean (Glycine max). Physiol. Plant. 83:463-468.

Carol RJ, Dolan L (2006) The role of reactive oxygen species in cell growth: lessons from root hairs. J. Exp. Bot. 57:1829-1834.

Chaparzadeh N, Amico ML, Nejad RK, Izzo R, Izzo FN (2004) Antioxidative responses of Calendula officinalis under salinity conditions. Plant Physiol. Biochem. 42:695-701.

Cavalcanti FR, Oliveira JTA, Martins-Miranda AS, Viegas RA, Silveira JAG (2004) Superoxide dismutase, catalase and peroxidase activities do not confer protection against oxidative damage in salt-stressed cowpea leaves. New Phytol. 163:563-571.

Cavalcanti FR, Lima JPMS, Ferreira-Silva SL, Viegas RA, Silveira JAG (2007) Roots and leaves display contrasting oxidative response during salt stress and recovery in cowpea. J. Plant Physiol.164:591-600.

Cramer GR, Läuchli A, Polito VS (1985) Displacement of calcium by sodium from the plasmalemma of root cells: primary response to salt stress. Plant Physiol. 79:207-211.

Croser C, Renault S, Franklin J, Zwiazek J (2001) The effect of salinity on the emergence and seedling growth of Picea mariana, Picea glauca, and Pinus banksiana. Environ. Pollut. 115:9-16.

Dionisio-Sese ML, Tobita S (1998) Antioxidant responses of rice seedlings to salinity stress. Plant Sci. 135:1-9.

Ferreira-Silva SL, Silveira JAG, Voigt EL, Soares LSP, Viégas RA (2008) Changes in physiological indicators associated with salt tolerance in two contrasting cashew rootstocks. Braz. J. Plant Physiol. 20:51-59. 
Foreman J, Demidchik V, Bothwell JHF, Mylona P, Miedema H, Torres MA, Linstead P, Costa S, Brownlee C, Jones JDG, Davies JM, Dolan L (2003) Reactive oxygen species produced by NADPH oxidase regulate plant cell growth. Nature 422:442-446.

Foyer $\mathrm{CH}$, Noctor $\mathrm{G}$ (2000) Oxigen processing in photosynthesis: regulation and signaling. New Phytol. 146:359-388.

Foyer CH, Noctor G (2005) Redox homeostasis and antioxidant signaling: A metabolic interface between stress perception and physiological responses. Plant Cell 17:1866-1875.

Freitas, J.B.S.: Respostas fisiológicas ao estresse salino de duas cultivares de feijão-caupi. [Physiologial responses of two contrasting cultivars of cowpea under salt stress]. - UFC, Fortaleza - Ceará 2006. [In Port.]

Gapper C, Dolan L (2006) Control of plant development by reactive oxygen species. Plant Physiol. 141:341-345.

Hamed KB, Youssef NB, Ranieri A, Zarrouk, M, Abdelly C (2005) Changer in content and fatty acid profiles of total lipids and sulfolipids in the halophyte Crithmum maritimum under salt stress. J. Plant Physiol. 162:599-602.

Havir EA, Mchale NA (1987) Biochemical and Developmental Characterization of Multiple Forms of Catalase in Tobacco-Leaves. Plant Physiol. 84:450455 .

Heath RL, Packer L (1968) Photoperoxidation in Isolated Chloroplasts .2. Role of Electron Transfer. Arch. Biochem. Biophys. 125:189-198.

Jebara M, Mohamed EA, Payre H, Jean-Jacques D (2005) Nodule conductance varied among common bean (Phaseolus vulgaris L.) genotypes under phosphorus deficiency. J. Plant Physiol. 162:309-315.

Jeschke WD, Aslam Z, Greenway H (1986) Effects of $\mathrm{NaCl}$ on ion relations and carbohydrate status of roots and on osmotic regulation of roots and shoots of Atriplex amnicola. Plant Cell Environ. 9:559-569.

Khan MH, Panda SK (2008) Alterations in root lipid peroxidation and antioxidative responses in two rice cultivars under $\mathrm{NaCl}$-salinity stress. Acta Physiol. Plant 30:91-89.

Kopyra M, Gwóźdź EA (2003) Nitric oxide stimulates seed germination and counteracts the inhibitory effect of heavy metals and salinity on root growth of Lupinus luteus. Plant. Physiol. Biochem. 41:1011-1017.

Lin CC, Kao CH (2002) Osmotic stress-induced changes in cell wall peroxidase activity and hydrogen peroxide level in roots of rice seedlings. Plant Growth Regul. 37:177-183.

Liszkay A, Kenk B, Schopfer P (2003) Evidence for the involvement of cell wall peroxidase in the generation of hydroxyl radicals mediating extension growth. Planta 217:658-667.

Maathuis FJM, Amtmann A (1999) $\mathrm{K}^{+}$nutrition and $\mathrm{Na}^{+}$toxicity: The basis of cellular $\mathrm{K}^{+} / \mathrm{Na}^{+}$ratios. Ann. Bot-London 84:123-133.

Maia JM, Voight EL, Macedo, CCE, Freitas JBS, Silveira JAG (2010) Antioxidative enzymatic protection in leaves of two constrating cowpea cultivars und salinity. Biol. Plant. 54(1): 159-163.

Mandhania S, Madan S, Sawhney V (2006) Antioxidant defense mechanism under salt stress in wheat seedlings. Biol. Plant. 50:227-231.
Meloni DA, Oliva MA, Martinez CA, Cambraia J (2003) Photosynthesis and activity of superoxide dismutase, peroxidase and glutathione reductase in cotton under salt stress. Environ. Exp. Bot. 49:69-76.

Mengel K, Kirkby EA (2001) Principles of Plant Nutrition. Kluver Academic Publishers, Dordrecht.

Mittler R (2002) Oxidative stress, antioxidants and stress tolerance. Trends in Plant Sci. 7:405-410.

Mittova V, Tal M, Volokita M, Guy M (2003) Up-regulation of the leaf mitochondrial and peroxisomal antioxidative systems in response to saltinduced oxidative stress in the wild salt-tolerant tomato species Lycopersicon pennellii. Plant Cell Environ. 26:845-856.

Møller IM, Jensen PE, Hansson A (2007) Oxidative modifications to cellular components in plants. Ann. Rev. Plant Biol. 58:459-481.

Munns R (2002) Comparative physiology of salt and water stress. Plant Cell Environ. 25:239-250.

Munns R, Tester M (2008) Mechanisms of salinity tolerance. Annu. Rev. Plant. Biol. 59:651-681.

Nakano Y, Asada K (1981) Hydrogen-peroxide is scavenged by ascorbatespecific peroxidase in spinach-chloroplasts. Plant and Cell Physiol 22:867880.

Passardi F, Penel C, Dunand C (2004) Performing the paradoxical: how plant peroxidases modify the cell wall. Trends Plant Sci. 9:534-540.

Rubinigg M, Wenisch J, Elzenga JTM, Stulen I (2004) NaCl salinity affects lateral root development in Plantago maritima. Funct. Plant Biol. 31:775780 .

Shanker AK, Djanaguiraman M, Sudhagar $R$, Chandrashekar CN, Pathmanabhan G (2004) Differential antioxidative response of ascorbate glutathione pathway enzymes and metabolites to chromium speciation stress in green gram (Vigna radiata (L.) R.Wilczek. cv C04) roots. Plant Sci. 166:1035-1043.

Sibole JV, Cabot C, Poschenrieder C, Barceló J (2003) Ion allocation in two different salt-tolerant Medicago species. J. Plant Physiol. 160:1361-1365.

Sreenivasulu N, Grimm B, Wobus U, Weschke W (2000) Differential response of antioxidant compounds to salinity stress in salt-tolerant and salt-sensitive seedlings of foxtail millet (Setaria italica). Physiol. Plant. 109:435-442.

Urbanek H, Kuzniakgebarowska E, Herka K (1991) Elicitation of Defense Responses in Bean-Leaves by Botrytis-Cinerea Polygalacturonase. Acta Physiol. Plant. 13:43-50.

Vaidyanathan H, Sivakumar P, Chakrabarty R, Thomas G (2003) Scavenging of reactive oxygen species in NaCl-stressed rice (Oryza sativa L.) - differential response in salt-tolerant and sensitive varieties. Plant Sci. 165:1411-1418.

Van Rossum MWPC, Alberda M, van der Plas LHW (1997) Role of oxidative damage in tulip bulb scale micropropagation. Plant Sci. 130:207-216.

Wahid A, Javed IUH, Ali I, Baig A, Rasul E (1998) Short term incubation of sorghum caryopses in sodium chloride levels: changes in some pre- and post-germination physiological parameters. Plant Sci. 139:223-232.

Yang YL, Guo JK, Zhang F, Zhao LQ, Zhang LX (2004) NaCl induced changes of the $\mathrm{H}^{+}$-ATPase in root plasma membrane of two wheat cultivars. Plant Sci. 166:913-918 